\title{
Angles
}

New Perspectives on the Anglophone World

$10 \mid 2020$

Creating the Enemy

\section{The Enemy Within: The Long Civil Rights Movement and the Enemy Pictures}

\section{Olivier Maheo}

\section{(2) OpenEdition}

1 Journals

\section{Electronic version}

URL: http://journals.openedition.org/angles/471

DOI: 10.4000/angles.471

ISSN: 2274-2042

\section{Publisher}

Société des Anglicistes de l'Enseignement Supérieur

\section{Electronic reference}

Olivier Maheo, «The Enemy Within: The Long Civil Rights Movement and the Enemy Pictures », Angles [Online], 10 | 2020, Online since 01 April 2020, connection on 28 July 2020. URL : http:// journals.openedition.org/angles/471; DOI : https://doi.org/10.4000/angles.471

This text was automatically generated on 28 July 2020

\section{(c) (i) (2) (2)}

Angles. New Perspectives on the Anglophone World is licensed under a Creative Commons AttributionNonCommercial-ShareAlike 4.0 International License. 


\title{
The Enemy Within: The Long Civil Rights Movement and the Enemy Pictures
}

\author{
Olivier Maheo
}

\section{Introduction: A Liberal Agenda}

1 The $20^{\text {th }}$ century could be described as the one that gave birth to a new "civilization of the image." (Gusdorf 1960: 11). By using images in its nation-building efforts, the United States has been a forerunner through what François Brunet called "Amériqueimage", a huge picture-book in which photographs of the Civil Rights Movement have a dedicated slot at a time when television was becoming a mass media (Brunet \& Kempf 2001). The best-known pictures of the Civil Rights Movement have thus become places of memory, iconic images testifying to the ultimate triumph of democracy.

2 If, according to W.E.B. Du Bois, "the problem of the twentieth century [was] the problem of the color-line," then photography may have been its main developer, not only by capturing the past in pictures and movies, but also by reasserting the color line and by confining African Americans to stereotypes (Du Bois 2007: 7). But photography was also used to mobilize people: activists of the movement, supporters of segregation, and the liberal media from the North. ${ }^{1}$

3 The close links between the Civil Rights Movement and photography and the media are well documented (Speltz 2016; Willis 2005; M. A. Berger 2011; Bezner 1999). Many photo reporters became famous through their pictures of the movement, notably Charles Moore, whose photographs were published in Life.

In this political battle, each side forged a stereotyped picture of its enemy. However, there were more than two sides. At least three types of visual discourse clashed: one in the southern segregationist press, one in mainstream discourse reproduced at length in the main northern media, and a lesser-known one produced by civil rights organizations. According to Julian Bond, who served as the communication director of 
the black student organization Southern Nonviolent Coordinating Committee (SNCC) from 1961 to 1965, "these pictures from the national broadcasting networks and nationally prominent news publications, [...] wholly white-owned, invariably whitestaffed and largely white oriented media crucially shaped popular perceptions of the Movement" (Bond 2001: 16). The SNCC developed a prolific communications Department headed by Bond. As communications secretary Mary King wrote: "It is no accident that SNCC workers have learned that if our story is to be told, we will have to write it and photograph it and disseminate it ourselves" (M. King 1988: 563).

The photographs from the mainstream media played an ambiguous role. They participated in the creation of two types of enemy which were a threat to democracy: the hateful and violent white supporter of segregation, and the similarly hateful and violent black nationalists. They provided potent testimonies against racism, but also circumscribed the movement to narrow legal objectives. I will argue that some pictures were not distributed as often precisely because they did not fit into these stereotypes, as with forgotten images of the Black Panther Party (BPP) which gave a different image of this organization contradicting its proven sexism. ${ }^{2}$

\section{Photography and the Movement}

6 The history of the Civil Rights Movement has undergone major change over the past twenty years with a new generation of historians. For Jacquelyn Dowd Hall (2005), there was a master narrative which watered down the history of the movement to better neutralize its contemporary significance. Her founding article posits that current political challenges are inseparable from the way the story is told. Instead of a single history of civil rights, a larger perspective has been developed within the history of the Black Freedom Movement that highlights the continuity between the struggle for legal equality of the civil rights movement to the broader and more radical aspirations of the 1960s and 1970s. For this reason, Jeanne Theoharis writes that we need to "shift our understanding beyond the dichotomy between the Civil Rights Movement and Black Power, both chronologically and ideologically" (Theoharis 2006: 352).

7 The growing role of the mass media after 1945 has been analyzed in various ways: an early limited-effects theory was first developed by Paul Lazarsfeld from 1945 (Lazarsfeld et al. 1948). Later proponents of a class-dominant theory, some of whom were active in the Frankfurt School, criticized this point of view and analyzed the media system from a class perspective (Adorno \& Bernstein 2007; Chomsky \& Herman 1988). In the 1980s, new culturalist approaches tended to emphasize the viewer's role (Hall 1973; McQuail 1983; Morley \& Hall 1986; Scannell 1994). With regards to the Civil Rights Movement, the role of the media in presenting a distorted vision of the events of the 1950s and 1960s has been extensively analyzed (Dennis 2011; Ward 2001; Martindale 1986; Weill 2002).

8 As far as the photographs of these events are concerned, they have increasingly become part of historical analysis (M. A. Berger 2011, 2014; M. Berger 2010; Raiford 2011; Phu 2008). However, it is only recently that lesser-known photographs have aroused interest and research has been carried out on, for example, the forgotten photographs showing the role of women in the Memphis janitors' strike of 1968 (Hamdan 2013). 
Civil rights activists had understood from the outset the essential role played by the media, starting with the role of images, even if they did not have at first the means to control their image in the mass media. Most of the famous photographs of the Civil Rights Movement were published in the northern newspapers by white editors whose political and aesthetic cannons corresponded to the political atmosphere of Cold War liberalism. This political consensus implied that white elites accepted advances on the racial question insofar as the black organizations supported their liberal policy against communism, including at the international level. Erik S. McDuffie calls this historical vision the "Horne thesis", after historian Gerald Horne, who showed how the Cold War had limited progress favoring African Americans (Horne 1986; McDuffie 2011). According to John Kaplan, in the 1950s and 1960s, Life was probably "the nation's most influential media outlet, reaching more citizens than any television program" (Kaplan 1999: 128). What images did Life produce and select to depict the movement?

\section{Reassuring Images of Racism: The Beauty and the Beast}

Before the "classical period" of the movement, between the Montgomery bus boycott in 1955 and the first Civil Rights Act in 1964, photographers like Gordon Parks began forging a new image of their community. ${ }^{3}$ In their work, photography reveals the beauty and power of the African American cultural experience, while documenting and affecting social change. The notion of visual representation as a powerful ideological force motivated W.E.B. Du Bois when he was the editor of the African American magazine The Crisis at the beginning of the $20^{\text {th }}$ century. ${ }^{4}$ Du Bois chose to publish positive images and beautiful black people as a way to counter the dominant discourse on Blacks as inferior beings. This notion prevailed in the Civil Rights Movement.

11 The illusion of reality gives photographs an authoritative status. Their mass production and circulation were helpful to create a counter-memory of the Black minority. If photography is closely connection with history, its relationship with history is neither direct nor obvious. A common illusion suggests photography reveals the past as it was. This illusion may be stronger in the American context because of a tradition of documentary photography which preaches objectivity. For Paul Strand, objectivity is the very essence of photography, but it may be rather considered as a form of memory: it has to do with emotions, feelings, storing images, and forgetting them (Strand 1917: 3). Memphis-born photographer Withers even defined it as "a collection of memories" (Willis 2002: 117). Instead of being historicized, photography needs to be socially and politically contextualized (Lugon 2004).

12 The link between the Civil Rights Movement, photography and the media is well documented, as with the image of Emmett Till's mutilated body which shocked the northern public (Tisdale 2002; Anderson \& Bond 2015; Bond et al. 2011). Mamie Till Bradley braved the authorities and imposed that her son's coffin should stay open. She tacked on the open lid a picture of her son taken on Christmas Eve, 9 months before his murder, juxtaposing his unrecognizable face with a joyful one. This association of competing images stirred indignation (see Figure 1). This picture was published first by Jet, an African American magazine founded in 1951, but it was kept hidden both by the southern white newspapers and the northern ones. Emmett Till's murder was poorly reported in two Mississippi white dailies (Grenada Sentinel Star and the Greenwood 
Commonwealth) whereas the black-owned Chicago Defender launched a campaign around the case (Spratt et al. 2007). Newspapers like the white-run Montgomery Advertiser labeled activists "outside agitators." For these newspapers, any coverage that could be in favor of civil rights would lead to economic or physical reprisals in the South (Walker 2001: 53). Birmingham newspapers only reported on segregationist Bull Connor's decision to unleash the dogs on civil rights demonstrators in 1963 after The New York Times published the pictures of black people being attacked by dogs. "It makes page one news everywhere except in Birmingham." (Alabama Public Radio 2013)

Figure 1. The body of Emmet Till (left) and a picture taken on Christmas Eve (right)
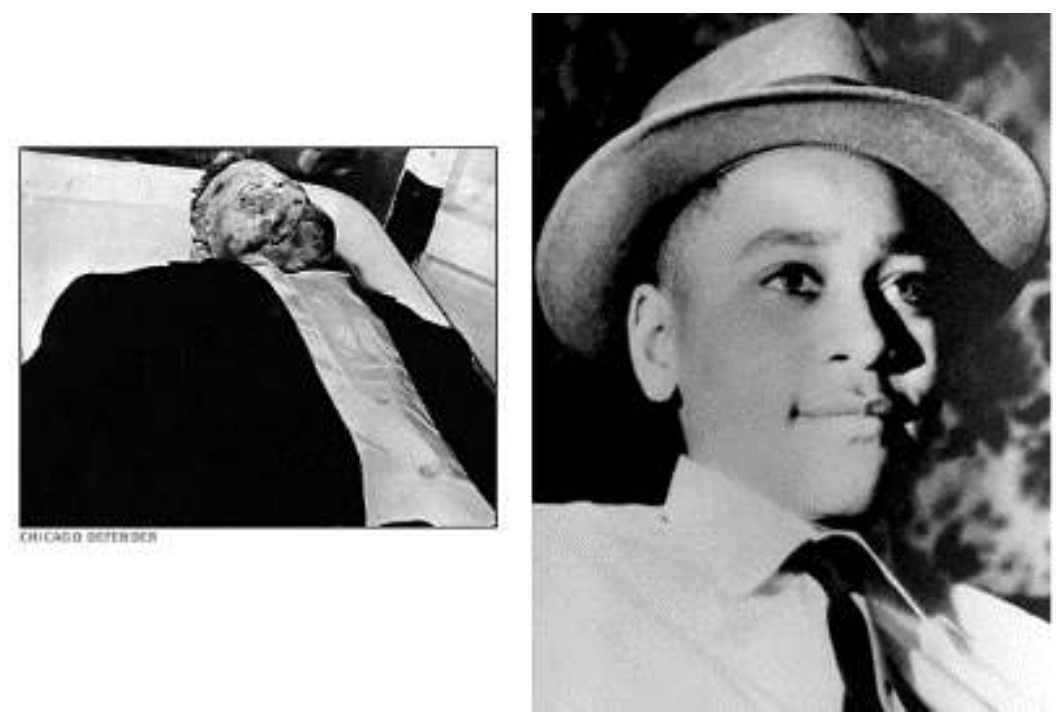

Source: https://en.wikipedia.org/wiki/File:Emmit_Till_body.jpg and https://en.wikipedia.org/wiki/ File:Emmett_Till.jpg

13 The photographs taken during the 1957 events in Little Rock, Arkansas, became places of memory to the movement. ${ }^{5}$ In 1954, the Supreme Court decision Brown v. Board of Topeka, Kansas officially ended school segregation. In Little Rock, 9 black students were selected by the black organization the NAACP to enroll in the city's Central High school. They were prevented from entering the school premises by the governor of the State, Orval Eugene Faubus (Snégaroff 2018; O'Hara 2010).

In 1954 it should be recalled that the same governor had already refused the racial integration of the university and therefore the admission of black students to a high school which, according to the law, had to implement desegregation. In a photo by the young Will Counts, 26 at the time, we see the violence of a young white woman, Hazel Massery, who screams at Elisabeth Eckford, one of the 9 black students admitted to this institution (Figure 2). 
Figure 2. Hazel Massery yells at Elisabeth Eckford

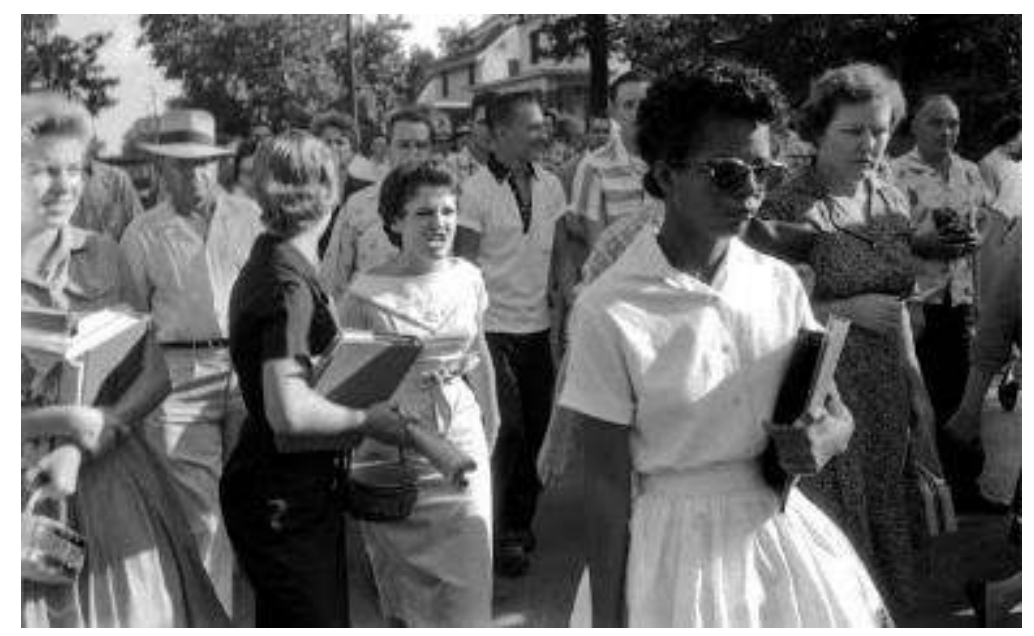

This attitude shocked the public at the time because it was the opposite of the restraint that a young girl from the South was supposed to adopt. The tactic of non-violence by black students often used the notion of respectability, which implies dignified behavior at all times, in effective opposition to the invective and violent acts of white supremacists in the South.

September 4, 1957, Will Counts Collection, Indiana University Archives

Sammie Dean Parker, standing on the far left of the picture (Chappell et al. 2004: 70) was leading the persecution against the 9 black students and was expelled from the high school for her violence. In spite of these tense days, in the midst of a strong stand against desegregation by white Southerners as the Civil Rights Movement was gaining momentum, the two women, Hazel and Elizabeth, became friends at the university, as revealed by David Margolick (2012). This photograph belongs to a rather broad category of violent images, which highlight the vicious behavior of some whites and put in place the figure of the hero-martyr.

There were many such photographs of violent situations in the northern mainstream press. For example the one taken by Bill Hudson of Walter Gadsden, a high school student who was attacked by police dogs in Birmingham on May 4, 1963 (Figure 3); or the one taken by Jack Thornell which shows James Meredith crawling after being hit by a bullet while walking in the March Against Fear in 1962 (Figure 4). There is also the image of Myrlie Evers crying at the funeral of her husband Medgar Evers in Jackson, Mississippi, on June 15, 1963. ${ }^{6}$ These pictures were selected for publication because they matched the editors' cannons from an aesthetic, political or narrative point of view (M. A. Berger 2014: 14). 
Figure 3. Walter Gadsden attacked by police dogs in Birmingham on May 4, 1963

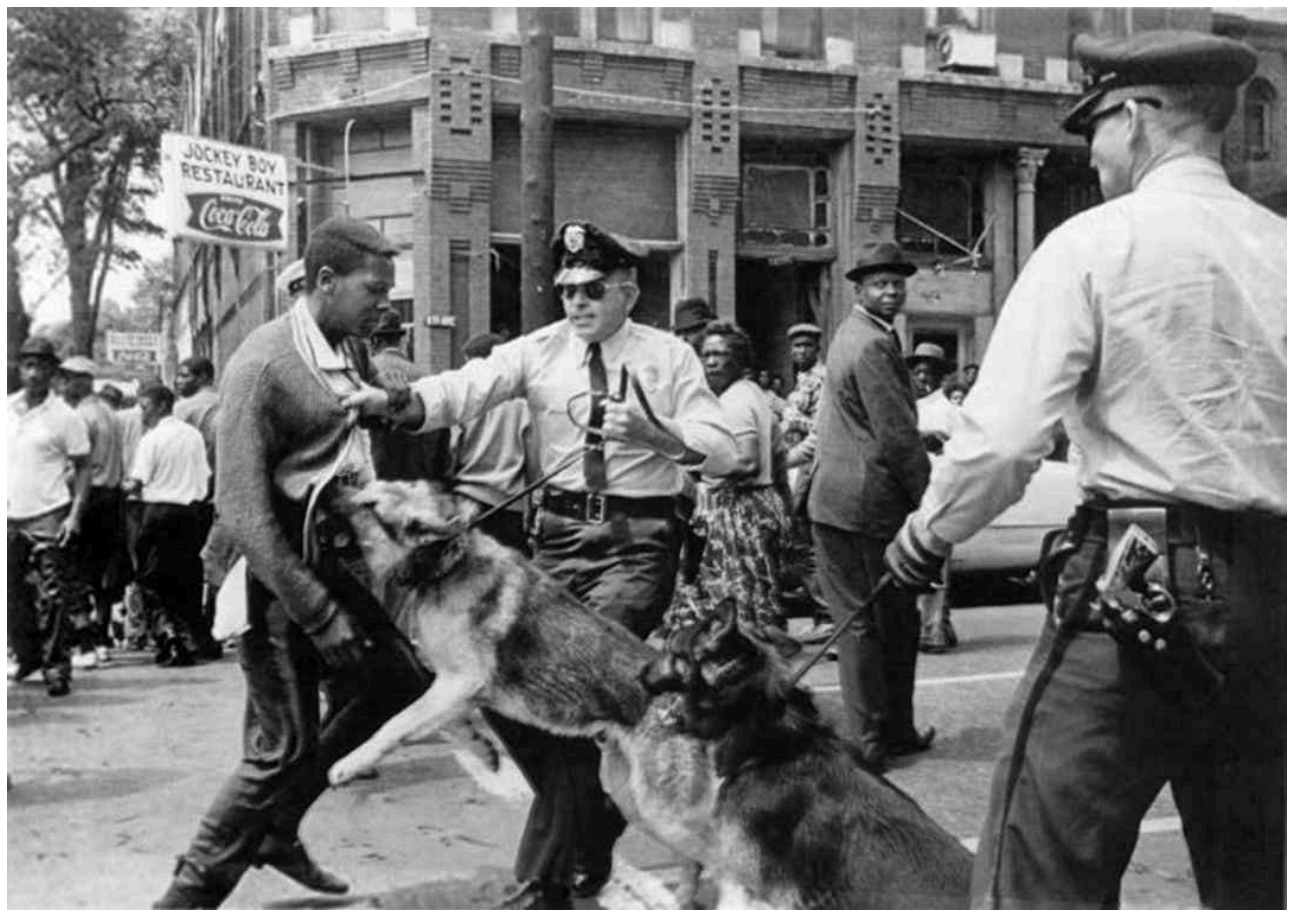

Photo by Bill Hudson for the New York Times

Source: https://eu.clarionledger.com/story/journeytojustice/2015/04/28/civil-rights-historymay-4/26502635

Figure 4. James Meredith grimacing in pain in Jackson, Miss, 1962

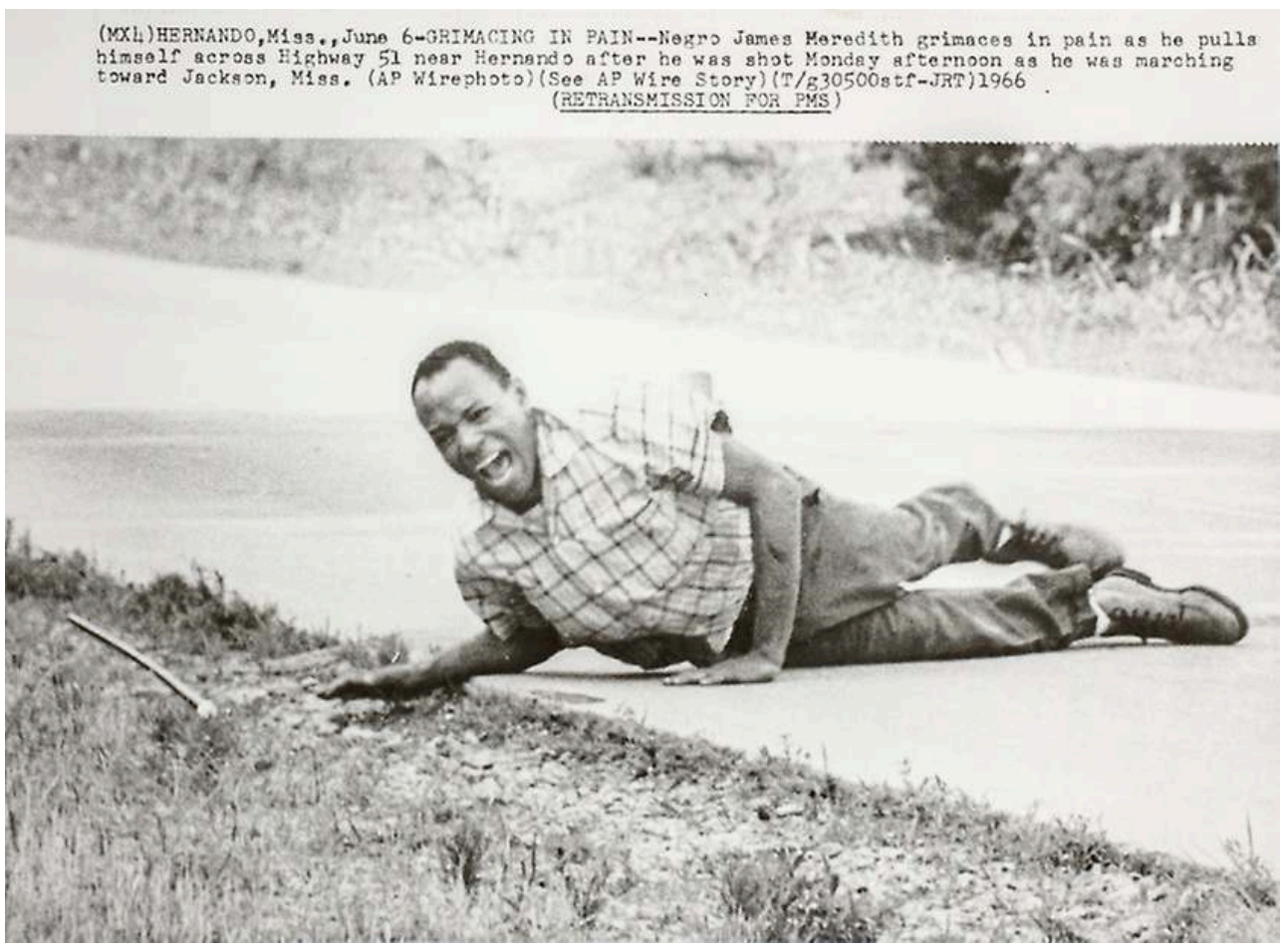

Jack Thornell for AP Wire

source: https://www.artic.edu/artworks/221739/james-meredith-grimacing-in-pain 

newspaper are numerous: an assignment that could originate from any editorial desk, this or that photographer being assigned to match work's schedules, moods and technical skills. A first selection is often made by the photographer himself. Then the editor's role is decisive (Ohrn 1983). When Charles Moores's photograph of Martin Luther King Jr. in a courtroom was published in Life Magazine, he had hoped that all of his 8 pictures would be published but the one chosen was the most quiet and less violent, making it impossible to understand the court's atmosphere and King's stand at the time (Kaplan 1999: 130). ${ }^{7}$ Media specialists defined a "gate keeping" system that determined which news was published or not: news items are stopped at 'gates' while a few others make their way to publication (Lewin 1947). Decisions are based on "news values" and affected by a myriad of individual, organizational and extra-media influences defined as "level of influences" (Shoemaker \& Reese 2013; Lowrey 1999; Galtung \& Holmboe Ruge 1965). More recently, Bednarek and Caple took images in their study about news values (Bednarek \& Caple 2012; de Smaele et al. 2017). The question of which image is selected, by whom and why is therefore complex.

Some of these images gained support and became "photo-events" about which Robert Taft acknowledges an "effect", an "impact" or an "influence" on national life and history (Taft 1938; Brunet 2011). As historian and critic Maurice Berger points out: "there is no question that visual images have influenced how Americans see and think about race. This is true because much of what defines race in society was, and is, innately visual" (M. Berger 2010: 6). Martin Luther King Jr. himself emphasized the power of photography in his 1964 book on violence in Birmingham.

The brutality with which officials would have quelled the black individual became impotent when it could not be pursued with stealth and remain unobserved. It was caught-as a fugitive from a penitentiary is often caught-in gigantic circling spotlights. It was imprisoned in a luminous glare revealing the naked truth to the whole world (M. L. King 2011: 30)

These pictures had a real impact: John F. Kennedy, after viewing the images of the terrible repression of the Children's Crusade using police dogs and fire hoses on his second day, May 3, 1963, said: "The civil rights movement should thank God for offering him Bull Connor. ${ }^{8}$ He helped him as much as Abraham Lincoln" (Nunnelley 1991: 3). Indeed, the extreme reaction of Whites to empowered black demonstrators influenced viewers who sympathized with the Civil Rights Movement. This was the objective sought by James Bevel in the Birmingham campaign of 1963. More broadly, the tactical non-violence adopted by the majority of the movement's activists followed the same strategy, largely based on communication through the media, including images.

One element in the arsenal of the modern civil rights movement, though, is rarely included in its history: the vast number of potent images, disseminated by new or enhanced technologies of visual communication that made their way into the culture at large. The struggle for racial justice in the United States was fought as assuredly on television and in movies, in magazines and newspapers, and through artifacts and images of everyday life as it was on the streets of Montgomery, Little Rock, and Watts (M. Berger 2010: 6)

The violence of the images could suggest that the denunciation they contain is proportional to it. However, racism in these images is disconnected from any social background. No ghetto here, no signs of poverty in rural areas, no fists raised. In this sense, these images - Elizabeth Eckford at Little Rock (Figure 2), the dogs of 
Birmingham in 1963 (Figure 3) - reassure us as to the innocence of the North, so far removed from a ferociously anti-segregationist and racist South (Garrow 2011: $\mathrm{x}$ ). This way of making the viewer feel ashamed about what was happening in the South of the nation and this call for white empathy does not mean that the viewer himself/herself should be convinced of the validity of racial equality, however. These photographs did not contradict the moderate line of the northern Liberals who blamed the situation on southern violence and not on economic exploitation.

21 The spatial dimension of this denunciation separates two spaces: the North, where civilized liberals looked with dismay at the inexplicable outburst of violence in a backward South; and the South. According to Martin A. Berger, this profusion of images absolved the Whites of the North of their fault and reassured them by giving them a formatted image of the South (M. A. Berger 2011: 152).

It is necessary to go beyond the face-to-face between the viewer, who interprets, and the photograph, which communicates, because these images were inserted in a framework, within the mainstream media of the North which guided their interpretation: southern brutality was exposed and denounced, and the liberals of the North would free blacks who were unable to do it by themselves (M. A. Berger 2011: 8). In this framework, African Americans largely remained victims who had neither power nor agency.

Liberal sympathy was not unconditional: it depended on the passivity and suffering of blacks. In 1965, the voter registration campaign launched by the SNCC and the Southern Christian Leadership Conference (SCLC) stalled and mobilizations were savagely repressed, as on "Bloody Sunday" on Sunday, March 7, 1965, when the Mounted Police charged the crowd of demonstrators. Martin Luther King Jr. then proposed an economic boycott in Alabama against all state products and asked Johnson to postpone any planned investment in Alabama. A relative of King, Stanley Levison, wrote to him about this:

The coalition of Selma and Montgomery, with its supporting millions, is not a coalition with an unrestricted program. It is a coalition around a fairly narrow objective. It is basically a coalition for moderate change, for gradual improvements which are to be attained without excessive upheavals as it gently alters old patterns. It is militant only against shocking violence and gross injustice. It is not for deep radical change. (Levinson 1965) ${ }^{9}$

Thus, it is possible to consider that the most striking images from the movement concurrently facilitated reforms and were an obstacle to more fundamental systemic changes, because they reassured and shocked at the same time. The questioning was limited to the segregationist practices of Jim Crow.

For this reason, these shocking photographs have had ambiguous effects. If many of them have become iconic images, it is by integrating them in an underlying discourse that is not free of racism. This may seem paradoxical, as the visual shock evokes obvious denunciation. But the call for pity goes hand in hand with a vision of dominated, struck-down blacks. These images perpetuate the control of black bodies by Whites. The photographs in the white press of the North reaffirmed white supremacy and its privileges, hence the absence of some of these images in the South, such as that of the mutilated Emmett Till, because this "visual absence" was correlated with the complex symbolic place that the black children occupied in the white imagination as they were viewed as adults, "adultified" (Hooks 2015: 115; Patton 2017: 47). 
Contrariwise, published images of the Black Power period could serve a simplistic and devaluing discourse.

\section{Scary images of Black Power: No More Mr. Nice Guy}

During its short history, between 1966 and 1974, after which the Black Panther Party (BPP) ceased to exist as a unified organization, the visual production of the Black Power movement was significant. The effectiveness of the Black Panthers' visual discourse was real: it combined photographs, drawings and collages (notably since 1971 by activist Gayle Dickson), illustrations and paintings - the best known by the party's "minister" of culture, Emory Douglas (Gayle 1971; Glover et al. 2014; Duncan 2016). This visual force indirectly resulted in its inclusion in the dominant narrative as a summary of Black Power in the broad sense.

As Peniel Joseph writes: “'black power' exists in the American imagination through a series of iconic, yet fleeting images - ranging from gun-toting Black Panthers (Figure 5) to black-gloved sprinters at the 1968 Mexico City Olympics (Figure 6) - that powerfully evoke the era's confounding mixture of triumph and tragedy" (Joseph 2001: 751). The Black Panthers' communication represents a true "policy of selfrepresentation" that has been much studied. I will not dwell on it (Rhodes 2007; Shames 2006; Duncan 2016; Fila-Bakabadio 2015) ${ }^{10}$.

Figure 5. Gun-toting Black Panthers invade the California Capitol in 1967

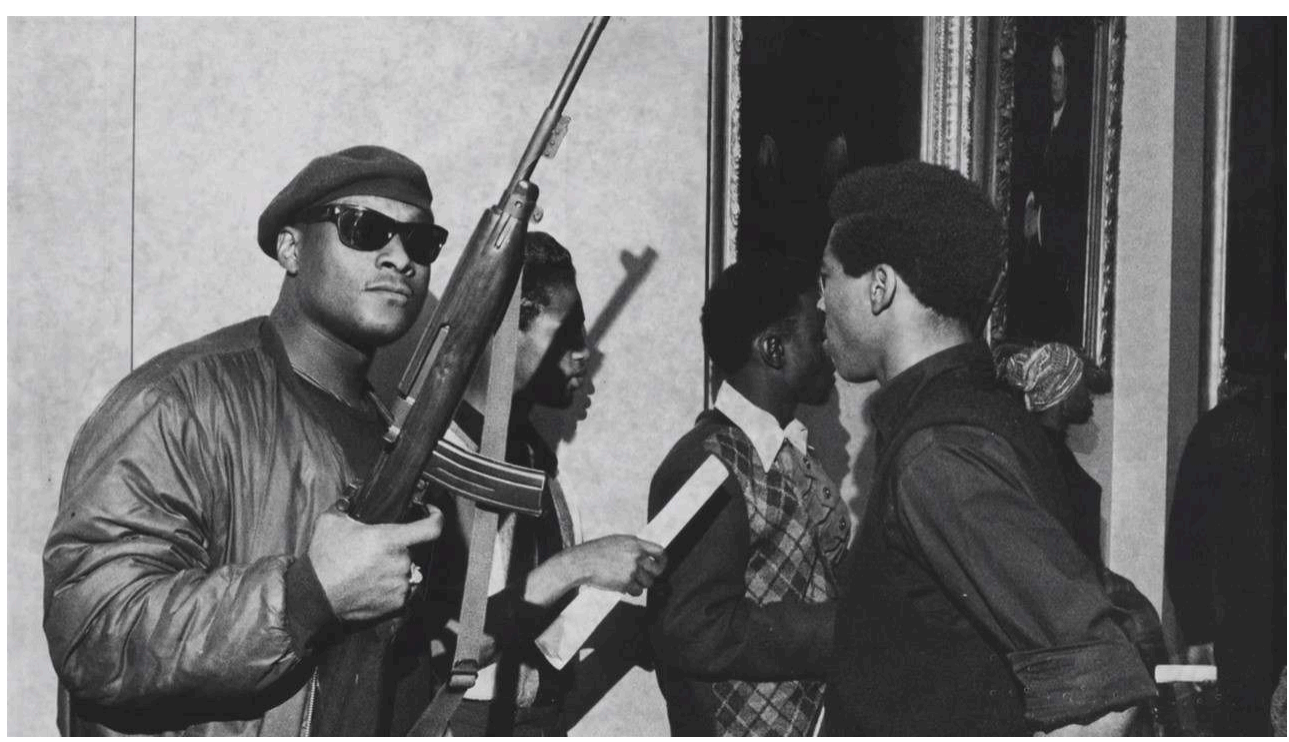

Source: https://www.sacbee.com/news/local/history/article148667224.html 
Figure 6. Black Power salute at the Mexico Olympics, 1968

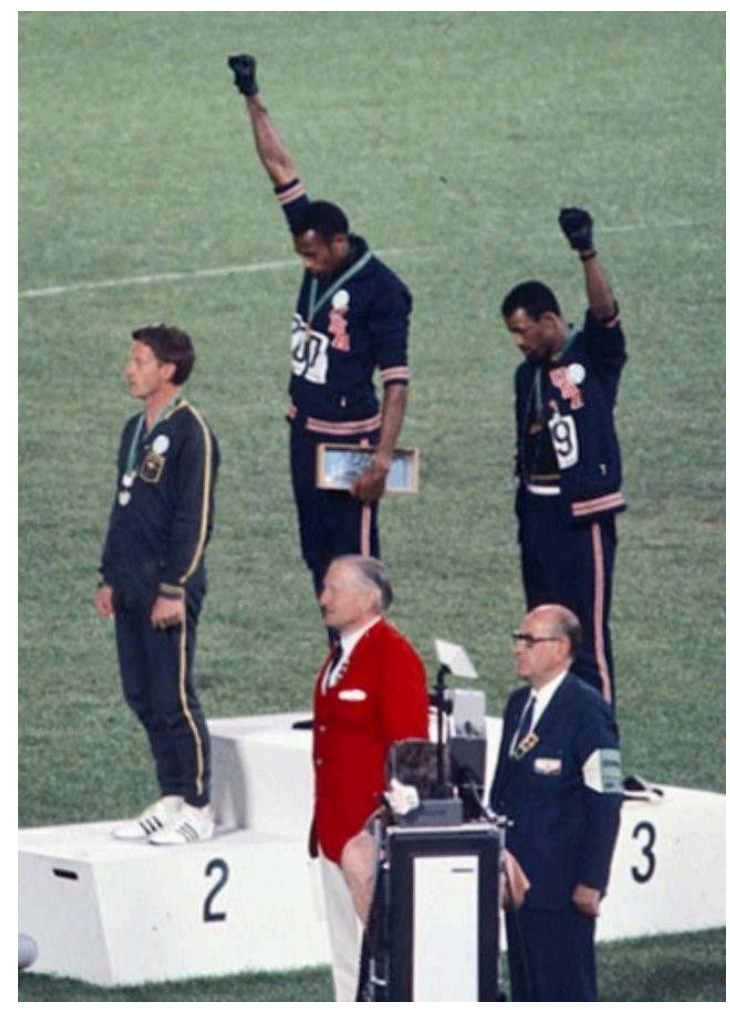

Source: https://en.wikipedia.org/wiki/1968_Olympics_Black_Power_salute\#/media/ File:John_Carlos,_Tommie_Smith,_Peter_Norman_1968cr.jpg

Janet Rhodes writes, "The Black Panthers played to the press, and the press responded with a flurry of prominent coverage. This was more than a strategy to attract attention; it was crucial to the way the group's leaders understood their mission" (Rhodes 2007: 90). 
Figure 7. Bobby Seale and Huey Newton, co-founders of the BPP, 1967, in front of their headquarters in Oakland, CA

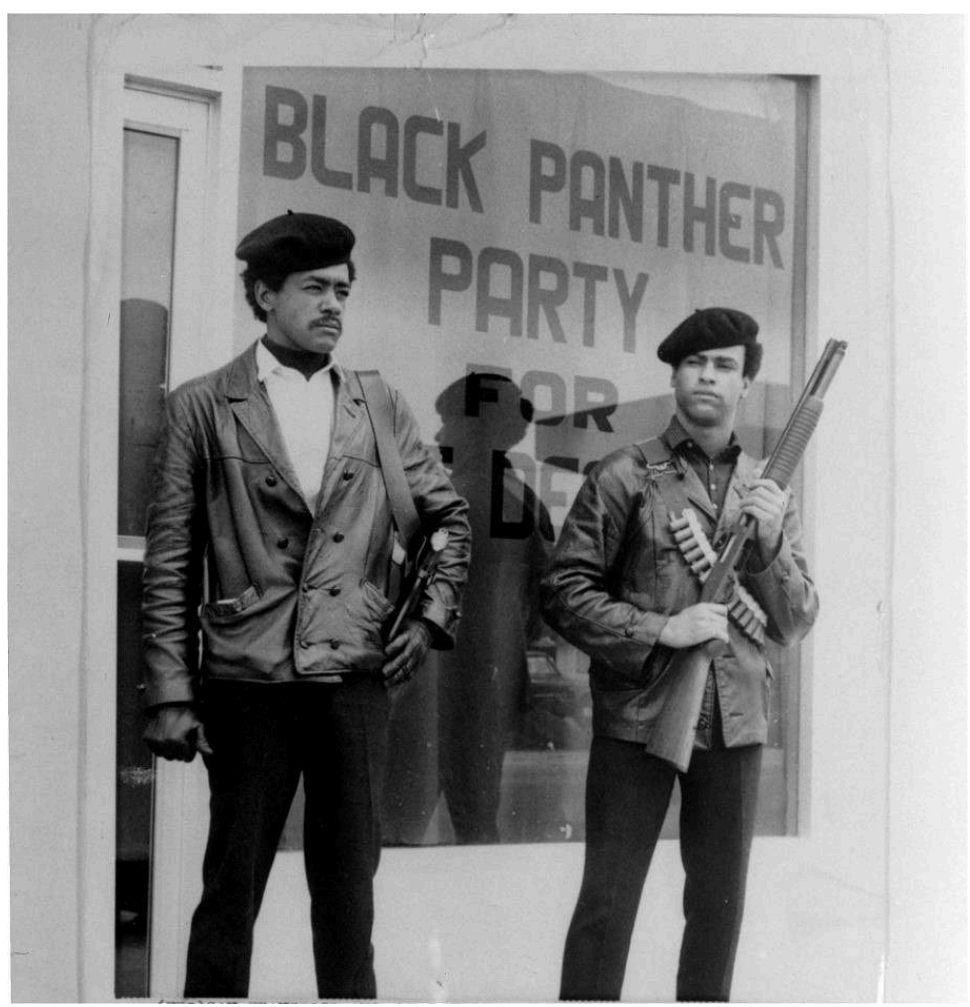

Source: 1967, Photo: Associated Press / San Francisco Examiner via http://pbs.org office they had just founded in 1966 in Oakland, California, the image was no longer the report of an event, but the event itself: it affirmed the visual identity of a new political group stressing their use of weapons (Figure 6). ${ }^{11}$ They were aiming to produce a visual discourse that could then be mobilized by the BPP (Raiford 2011: 190-5). famous ones from the Black Panther Party, with raised fists, afro-cuts and leather jackets, participate in the stereotypical view of the "bad nigger" as defined by historian Riché Richardson (Richardson 2007, 34-37). The Panther's well-known demonstrations with weapons and berets can be likened to a "policy of disrespect", far removed from the policy of respectability stressed by the civil rights organizations (Higginbotham 1993: 49-50)..$^{12}$

In fact, most of the violence actually originated from the government's own COINTELPRO plan, an FBI project against any organization supposed to be a threat to democracy (Blackstock 2001; Goldstein 2001). ${ }^{13}$ For the Oakland area alone, Charles E. Jones listed 5 raids, 4 shoot outs, 26 espionage actions and 92 legal actions against the BPP between 1966 and 1971 (Jones 1988: 423). In the earlier period, the press was inclined to ignore or downplay any incident of black violence or inflammatory rhetoric", putting the emphasis on the liberal agenda of the SLCL (Walker 2001, 48). But current research shows that violence was part and parcel or the nonviolent movement, which thus makes it possible to link between the two periods of the movement, i.e. the civil rights campaigns until 1964, and the Black Power era that followed (Shapiro 1988; Cobb 2014; Strain 2005; Crosby 2011). 
It should be noted, however, that the most disseminated images of the BPP where those which evoked violence. They tended to simplify its history in two ways: first by limiting this organization to violence and, secondly, by summing up the whole period to the role played by the BPP. It is now possible to reverse this assertion: if these images were so widely disseminated and elevated to iconic status, it is precisely because they fit perfectly into the dominant narrative that made Black Power the "evil twin that wrecked the civil rights" (Joseph 2001: 2). These images often corresponded to what the white editors wanted to show: "While the white media could have selected any number of stories to tell they consistently framed the story as a narrative of spectacular violence" (M. A. Berger 2011: 3). In this narrative,

Hard divisions between the groups involved have allowed the civil rights movement to be hailed as the harbinger of important democratic surges and Black Power to be portrayed as a destructive, at times blatantly misguided movement that promoted rioting over political legislation, violence over diplomacy, and racial separatism over constructive interracial engagement (Joseph 2009: 103-9).

Yet other views of the BPP existed in the 1960s, but they did not reach the same visibility, perhaps because they do not have the same sensationalist appeal associated with guns, martial poses and other provocative gestures. Unsurprisingly, these other pictures did not fit into the frightening vision relayed by the mainstream press.

\section{Breakfast in Oakland: Invisible Images of the Panthers}

Pictures of the BBP that did not represent violence and provocation were found mostly in the BPP's own newspaper, The Black Panther, and other militant publications. These lesser-known photographs did not become icons precisely because they do not correspond to the preconceived discourse about the BPP, as is the case with the photograph of a party activist in Kansas City one morning in 1969 (Figure 7). The young BPP militant waiter, without an afro haircut or a black beret but with an apron usually associated with women, serves breakfast to children sitting at tables.

Although these programs were nonviolent, they were considered as a threat by the FBI and targeted by covert actions with letters to the main contributors and donors (Mayfair Market, Safeway Stores) to dissuade them from helping BPP-related programs (Jones 1988: 425). 
Figure 8. Bill Whitfield, Black Panther Party in Kansas City, serving breakfast to children, 16 April 1969

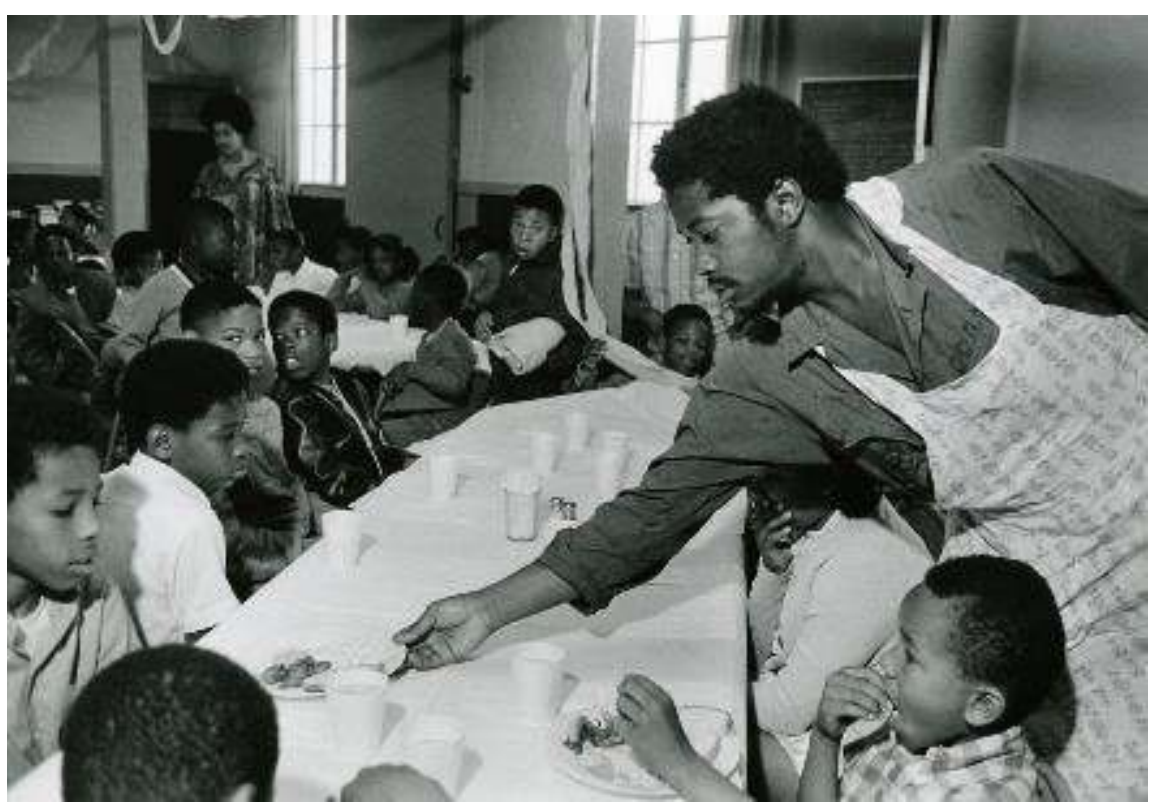

Source: William P. Straeter, AP, https://www.nationalgeographic.com/people-and-culture/food/theplate/2015/11/04/the-black-panthers-revolutionaries-free-breakfast-pioneers

stereotypes are here rejected. First, that of a task usually associated with women in gendered maternal role assignments. The BPP that was created with hypermasculinized representations evolved around that time as many male leaders had been killed or arrested and more and more women joined its ranks. Second, this photograph is far from the clichés of a party reduced to provocative images of martial military type meant to display the claim of revolutionary violence. Finally, this image runs counter to the vision of a party tied primarily to the ghettos of California, Chicago or the East Coast, as the scene is set in Kansas City, in the Midwest.

The breakfasts offered by the BPP were part of the Community Programs that the organization had been developing starting in 1969. The Free Breakfast Program, or Breakfast for Children Program, represented a shift in BPP policy. Leader Elridge Cleaver was no longer present as he had taken refuge in Cuba after a shootout against the Oakland police in April 1968. On July 3, 1969, from Algiers, Stokely Carmichael announced his break with the party which he blamed for its attacks against cultural nationalists (Joseph 2007: 243). At that time, BPP local branches adopted increasingly diverse policies and self-help programs which Huey Newton called "Survival Programs", from community ambulance systems to free clinics (Abron 1998). But the most successful was the free breakfast program for children which at its height involved 45 programs around the country (Heynen 2009; Black Panther Party 1971).

From 1970 onwards, other representations appeared in the party's newspaper. They reflected the shift towards Community Programs. In 1969, The Black Panther declared for the first time that women were equal to men and recommended that activists treat them as such, while Fred Hampton of the Chicago BPP held a meeting on the subject of sexism in a section of the party admittedly known to have been rather more progressive than what was commonly said within the BPP on this issue. Among the new activist figures were Gayle Dickson's illustrations showing images of older women, two 
of whom, for example, held their shopping wrapped in the party newspaper, one of which showed the slogans of Bobby Seale's campaign for Oakland City Hall in 1973 (Figure 8), and the other the announcement of the party's "Free Food Program" for the poorest people (Figure 9) (Farmer 2017, 85-89). ${ }^{14}$ Obviously, BPP sympathizers and militants were not just angry young men.

Figure 9. Illustration by Gayle Dickson, in the BPP newspaper The Black Panther, July $1^{\text {st }} 1972$

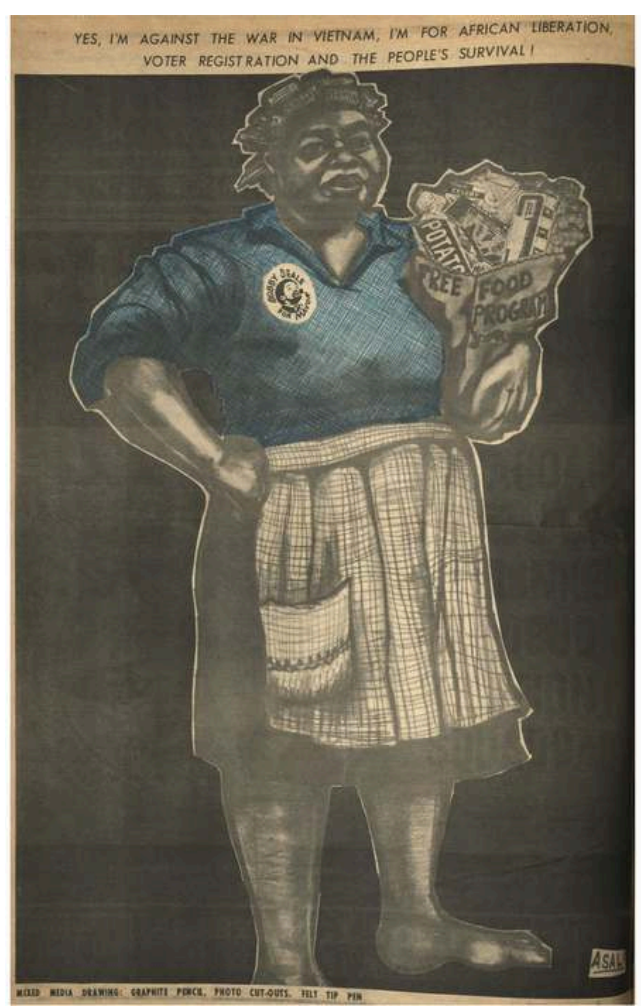

Source: Farmer 2017 
Figure 10. Illustration by Gayle Dickson: "Let it shine"

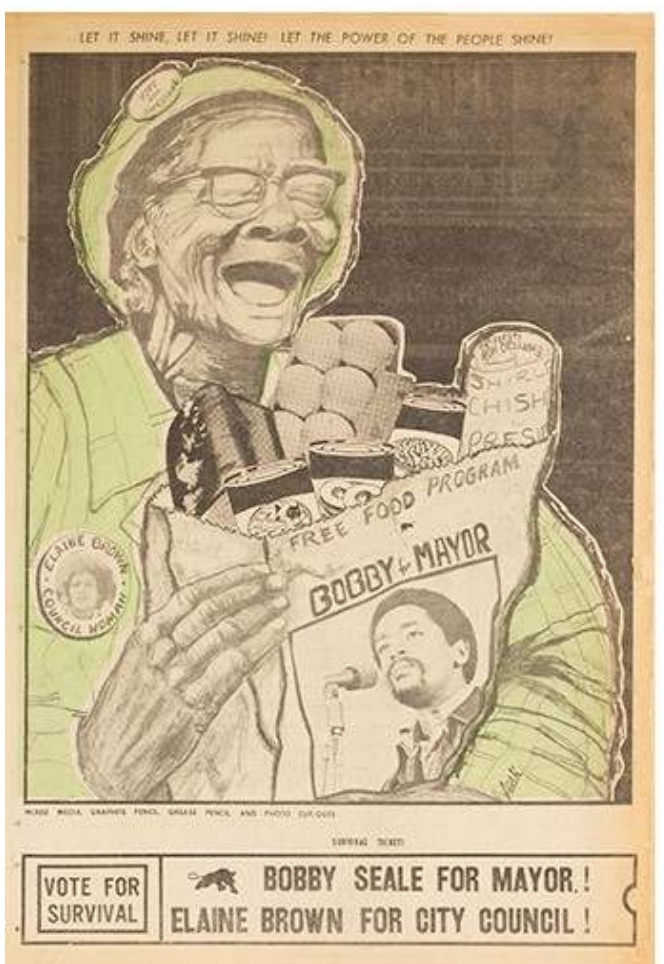

Source: The Black Panther Intercommunal News Service, June 3, 1972 of David Hilliard with his family (Figure 10, below). Baruch and Pirkle, a photographer couple, were white sympathizers of the leftist Californian Peace and Freedom Party. Kathleen and Elridge Cleaver gave their consent and allowed them to follow party members anywhere, but these types of images were hardly found in the press and mainstream media (Phu 2008; Cleaver and Katsiaficas 2001; Henderson 2001). 
Figure 11. Jones, Pirkle, Portrait of "Captain" David Hilliard, Chief of Staff of the Black Panther Party, at Bobby Hutton Memorial Park, surrounded by his wife, three sons and a daughter, Oakland, California, No. 152

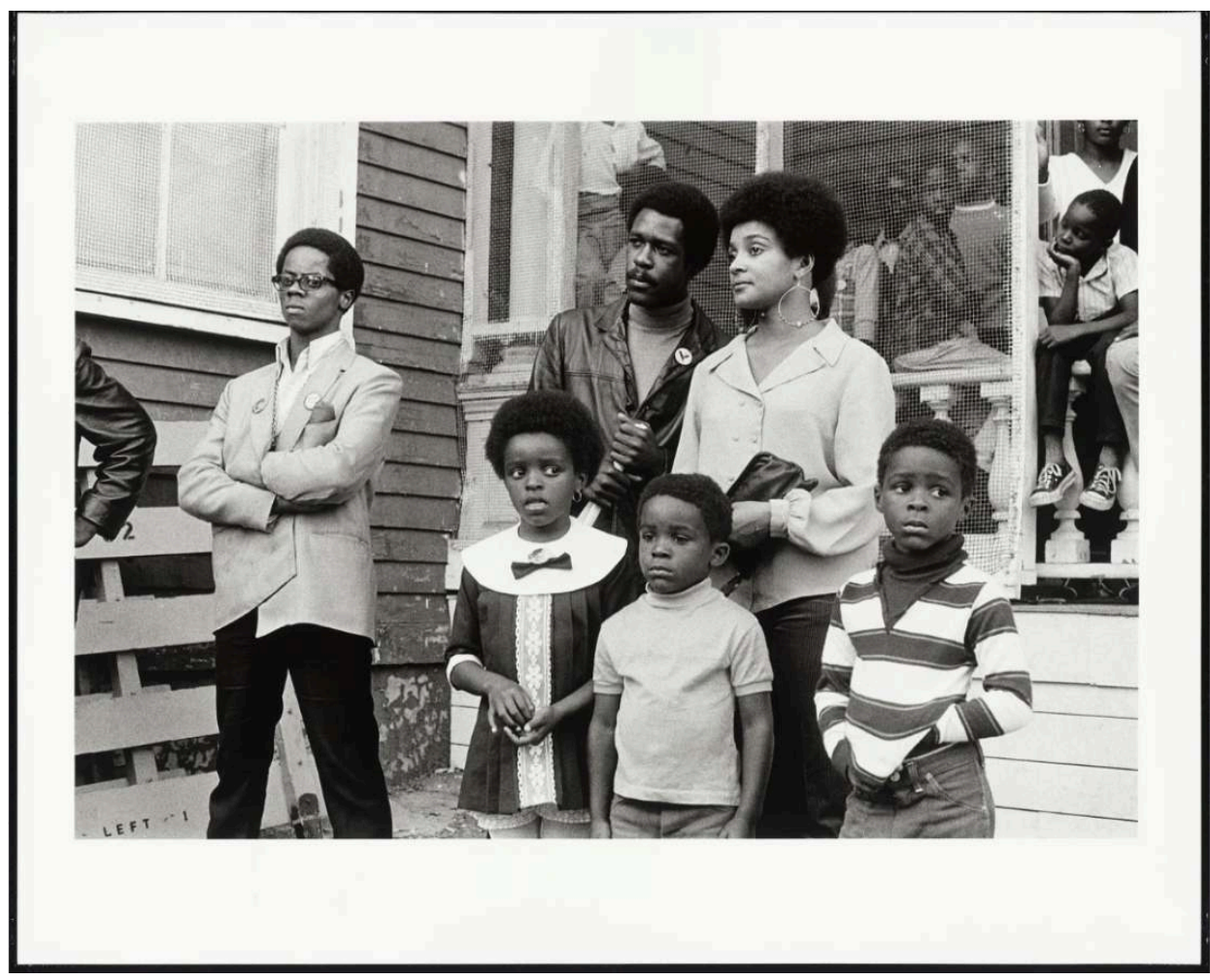

Source: Baruch and Jones 1970: 103

41 Indeed, these pictures did not fit the general trend of vilification of black activists linked to the Black Power movement. To this day, these other figures of the Party are virtually unknown compared to the provocative images through which the BPP tried to assert a new political identity. Its violence was more symbolic than real, unlike the forceful state repression, but what mostly remains today in collective memory are the confrontational images, especially still widely used whenever this period is mentioned in the media.

The BPP had a very conscious policy regarding the pictures it produced, like the SNCC before them. They acted in a provocative way, displaying their rifles and gloved fists. As Jean Genet argued, they attacked first by sight ("Jean Genet chez les Panthères noires" 2000; Genet 2009: 291). Unlike the BPP, other groups like the League of Revolutionary Black Workers founded in Detroit in 1968 felt it was better to remain secretive, and when they chose to react with violence, they did so without boasting about it.

In the end, the more the images were provocative, the more they became part of American collective memory, and provided the US Government with the image of a perfect enemy against whom any type of action was acceptable.

\section{Conclusion}

44 Many photographs about the Black Freedom Movement have been often analyzed from the point of view of their content and of their reception: according to Michele Giordano 
(1981) most historical analyses were limited to these aspects. For Michel Frizot (1996: 57), "All photography is history by nature", ${ }^{15}$ but this false evidence of the scene photographed arouses more mistrust than enthusiasm. Antoine Prost similarly warns us: "Photography carries conviction: how could film not have fixed the truth?"16 (About \& Chéroux 2001) Photojournalism cannot be understood outside the economic and editorial context that led to the selection of specific images. The reading of an image for its documentary value must take into account the contributions of media sociology in order to consider the context of its production (Becker 2001; Meyer 2017). Thus, our research suggests photography has been defined as an instrument of ambivalent power invested both by protesters and by those in power (Cuny \& Nez 2013).

The northern media created a two-sided picture of the black activists. First, there was a reassuring image of racism, in which the enemy was the openly racist white supremacist from the old South which exonerated the northern liberal from racist bias. In these pictures, the southern black activists are viewed as helpless victims, like Rosa Parks in the best-known pictures of her. Second, black nationalists were later portrayed as ferocious individuals or as part of a violent mob. This type of Black Power activist found its counterpart in films and pulp fictions in which black villains, hustlers, dealers, pimps and gangsters were associated with activism, as William Van Deburg has shown (Van Deburg 2001: 207-8; 2004). The BPP and its glorification of the lumpen did not break up with this scheme. In his 1971 film, Sweet Sweetback's Baadasssss Song, Melvin Van Peebles's hero plays with this stereotype. Escaping from the police at the end of the film by fleeing to Mexico, the hero proclaims: "Watch out. A baad asssss nigger is coming back to collect some dues" (Van Peebles \& Kanopy 1971; Letort 2009). However, this contribution has attempted to show that a different visual discourse existed, only it was rarely taken up by mainstream media.

\section{BIBLIOGRAPHY}

About, Ilsen, and Clément Chéroux. "L'histoire par la photographie." Études photographiques, no. 10. November 2001: 8-33. https://journals.openedition.org/etudesphotographiques/261

Abron, JoNina. “'Serving the People': The Survival Programs of the Black Panther Party.” In Charles E Jones. Black Panther Party Reconsidered: Reflections and Scholarship, New York: Black Classic Press, 1998.

Adorno, Theodor Wiesengrund, and Jay M Bernstein. The Culture Industry: Selected Essays on Mass Culture. London; New York: Routledge, 2007

Alabama Public Radio. "How The Media Covered The Civil Rights Movement: The Children.” 2013. https://www.apr.org/post/how-media-covered-civil-rights-movement-childrens-march, 2013.

Anderson, Devery S, and Julian Bond. Emmett Till: The Murder That Shocked the World and Propelled the Civil Rights Movement. Jackson, Ms.: UP of Mississippi, 2015.

Baruch, Ruth-Marion, and Pirkle Jones. The Vanguard: A Photographic Essay on the Black Panthers. Boston: Beacon Press, 1970. 
Becker, Howard S. "Sociologie visuelle, photographie documentaire et photojournalisme." Communications 71 (1) 2001: 333-51. doi: 10.3406/comm.2001.2091.

Bednarek, Monika, and Helen Caple. News Discourse. London: Bloomsbury.

Berger, Martin A. 2011. Seeing through Race: A Reinterpretation of Civil Rights Photography. Berkeley: U. of California P., 2012.

Berger, Martin A. Freedom Now! Forgotten Photographs of the Civil Rights Struggle. Berkeley: U. of California P., 2014.

Berger, Maurice. For All the World to See: Visual Culture and the Struggle for Civil Rights. New Haven, Conn.: Yale UP, 2010.

Bezner, Lili Corbus. Photography and Politics in America: From the New Deal into the Cold War. Baltimore, Md.: The Johns Hopkins UP, 1999

Black Panther Party. Once Again: Free Breakfast Program: Start Oct. 25, 1971. Philadelphia: Black Panther Party, 1971.

Blackstock, Nelson. COINTELPRO: The FBI's War on Political Freedom. New York; London: Pathfinder, 2001.

Bond, Julian. "The Media and the Movement: Looking Back from the Southern Front." In Brian Ward. Media, Culture, and the Modern African American Freedom Struggle, Gainesville, Fl.: UP of Florida, 2001.

Bond, Julian, Clayborne Carson, Matt Herron, and Charles E. Jr Cobb. This Light of Ours: Activist Photographers of the Civil Rights Movement. Leslie G. Kelen (ed.). Jackson, Ms.: UP of Mississippi, 2011.

Brown, Elaine. A Taste of Power: A Black Woman's Story. New York: Pantheon Books, 1992.

Brunet, François. "L'histoire photographique de l'Amérique selon Robert Taft (Photography and the American Scene, 1938)." E-rea. Revue électronique d'études sur le monde anglophone 8.3 (June) 2011. doi : 10.4000/erea.1777.

Brunet, François. L'Amérique des images: histoire et culture visuelles des États-Unis. Paris: Hazan / Université Paris 7 Diderot, 2013.

Brunet, François, and Jean Kempf.. “Avant-propos au dossier l'Amérique-image.” Revue Française d'Études Américaines, no. 89. 2001: 3-9.

Chappell, Marisa, Jenny Hutchinson, and Brian Ward. "'Dress Modestly, Neatly - as If You Were Going to Church': Respectability, Class, and Gender in the Montgomery Bus Boycott and the Early Civil Rights Movemen." In Peter Ling and Sharon Monteith (eds.). Gender and the Civil Rights Movement. New Brunswick, N.J.: Rutgers UP, 2004 69-100.

Chomsky, Noam, and Edward S. Herman. Manufacturing Consent: The Political Economy of the Mass Media. Londres: Random House, 1988.

Cleaver, Kathleen, and George N Katsiaficas. Liberation, Imagination, and the Black Panther Party: A New Look at the Panthers and Their Legacy. New York: Routledge, 2001.

Cobb, Charles E. This Nonviolent Stuffll Get You Killed: How Guns Made the Civil Rights Movement Possible. New York: Basic Books, 2014.

Crosby, Emilye. Civil Rights History from the Ground Up: Local Struggles, a National Movement. Athens, Ga.: U. of Georgia P., 2011. 
Cuny, Cécile, and Héloïse Nez. "La photographie et le film : des instruments de pouvoir ambivalents." Participations 7 (3) 2013: 7-46. doi: 10.3917/parti.007.0005

Dennis, Everette E and Pease Edaward. The Media in Black and White. New Brunswick, NJ: Transaction Publishers, 2011.

Dibari, Michael Jr. Advancing the Civil Rights Movement. Race and Geography of Life Magazine's Visual Representation, 1954-1965. Lexington: Lexington Books, 2017.

Du Bois, William Edward Burghardt. Les âmes du peuple noir. Paris: La Découverte, 2007.

Duncan, Mary. "Emory Douglas and the Art of the Black Panther Party." Spectrum: A Journal on Black Men 5 (1) 2016: 117-35. doi: 10.2979/spectrum.5.1.06

Farmer, Ashley D. Remaking Black Power: How Black Women Transformed an Era. U. of North Carolina P., 2017.

Fila-Bakabadio, Sarah. "Photographier depuis la marge : Notes sur l'histoire politique afroaméricaine.” GRAAT On-Line Issue 18 (2015). http://www.graat.fr/margin09.pdf

Frizot, Michel. "Faire Face, Faire Signe. La Photographie, Sa Part d'histoire.” In Jean-Paul Ameline. Face à l'histoire 1933-1996. L'artiste Moderne Devant l'événement Historique. Paris: Flammarion/Centre Georges-Pompidou, 1996: 49-57.

Galtung, Johan, and Mari Holmboe Ruge. "The Structure of Foreign News.” Journal of Peace Research 1965 (1) 1965: 64-92. https://www.jstor.org/stable/423011

Garrow, David J. “Foreword.” In Martin A. Berger (ed.). Seeing through Race: A Reinterpretation of Civil Rights Photography. Berkeley, Ca.: U. of California P., 2011: ix-xii.

Gayle, Addison. The Black Aesthetic. Garden City, N.Y.: Doubleday, 1971.

Genet, Jean. Un captif amoureux. Paris: Gallimard, 2009.

Giordano, Michele. “Fotografia e storia." Studi Storici 22 (4) 1981: 815-32.

Glover, Danny, Bobby Seale, Sam Durant, Sonia Sanchez, Kathleen Cleaver, Colette Gaiter, Greg Jung Morozumi, Amiri Baraka, and St. Clair Bourne. Black Panther: The Revolutionary Art of Emory Douglas. New York: Rizzoli, 2014.

Goldstein, Robert Justin. Political Repression in Modern America: From 1870 to 1976. Urbana: U. of Illinois P., 2001.

Gore, Dayo F., Jeanne Theoharis, and Komozi Woodard. Want to Start a Revolution? Radical Women in the Black Freedom Struggle. New York: NYU Press, 2009

Gusdorf, Georges. "Réflexions sur la civilisation de l'image." Recherches et débats du Centre catholique des intellectuels français, Nouvelle Série 33 (1960): 11-34.

Hall, Stuart. Encoding and Decoding in the Television Discourse. Birmingham: Univ. of Birmingham, 1973. https://www.birmingham.ac.uk/Documents/college-artslaw/history/cccs/stencilledoccasional-papers/1to8and11to24and38to48/SOP07.pdf

Hamdan, Leila I. “Culture and Resistance: Civil Rights Photography: Memphis, 1968." Fire!!! 2 (2) 2013: 109-48. doi: 10.5323/fire.2.2.0109

Henderson, Errol A. "Shadow of a Clue" In Kathleen Cleaver and George N Katsiaficas (eds.). Liberation, Imagination, and the Black Panther Party: A New Look at the Panthers and Their Legacy, New York: Routledge, 2001: 197-207.. 
Heynen, Nik. "Revolutionary Cooks in the Hungry Ghetto: The Black Panther Party's Biopolitics of Scale from Below." In Roger Keil and Rianne Mahon (eds.). Leviathan Undone? Towards a Political Economy of Scale. Vancouver: UBC, 2009: 265-80.

Higginbotham, Evelyn Brooks. Righteous Discontent: The Women's Movement in the Black Baptist Church, 1880-1920. American Mathematical Soc., 1993.

Hooks, Bell. Black Looks: Race and Representation. New York: Routledge, 2015.

Horne, Gerald. Black and red: W.E.B. Du Bois and the Afro-American response to the Cold War: 1944-1963. New York: State University of New York Press, 1986.

Huggins, E., and Angela D LeBlanc-Ernest. "Revolutionary Women, Revolutionary Education: The Black Panther Party's Oakland Community School." In Dayo F. Gore, Jeanne Theoharis, and Komozi Woodard (eds.). Want to Start a Revolution? Radical Women in the Black Freedom Struggle. New York: NYU Press, 2009: 161-84.

Jones, Charles E. "The Political Repression of the Black Panther Party 1966-1971: The Case of the Oakland Bay Area." Journal of Black Studies 18 (4) 1988: 415-34.

https://www.jstor.org/stable/2784371

Joseph, Peniel E. "Black Liberation Without Apology: Reconceptualizing the Black Power Movement.” Black Scholar 31 (3/4) 2001: 2-19. https://www.jstor.org/stable/41069810

Joseph, Peniel E. "The Black Power Movement: A State of the Field." The Journal of American History 96 (3) 2009: 751-776. doi: 10.1093/jahist/96.3.751

Kaplan, John. “The Life Magazine Civil Rights Photography of Charles Moore.” Journalism History 25 (4) 1999: 126-39. doi: 10.1080/00947679.2000.12062526

King, Martin Luther. Why We Can't Wait. Boston: Beacon Press, 2011.

King, Mary. Freedom Song: A Personal Story of the 1960s Civil Rights Movement. New York: Morrow, 1988.

Lazarsfeld, Paul F, Bernard Berelson, and Hazel Gaudet. The People's Choice: How the Voter Makes up His Mind in a Presidential Campaign. New York: Duell, Sloan and Pearce, 1944.

LeBlanc-Ernest, Angela D, and Charles E. Jones. "The Most Qualified Person to Handle the Job." In Jones Charles Earl (ed.). Black Panther Party Reconsidered: Reflections and Scholarship. Batimore, Md.: Black Classic Press, 1998: 161-84.

Letort, Delphine. “Sweet Sweetback's Baadasssss Song de Melvin Van Peebles (1971) : exégèse d'un film militant." Revue LISA/LISA e-journal. Littératures, Histoire des Idées, Images, Sociétés du Monde Anglophone - Literature, History of Ideas, Images and Societies of the English-speaking World VII.1 (January) 2009: 74-88. doi: 10.4000/lisa.790.

Levinson, Stanley. Letter to King, 7 April 1965. Archives / King Center. http:// www.thekingcenter.org/archive

Lewin, Kurt. Frontiers in Group Dynamics: Concept, Method and Reality in Social Science: Social Equilibria and Social Change. Indianapolis: Bobbs-Merrill, 1947.

Lowrey, Wilson. "Routine News: The Power of the Organization in Visual Journalism." Visual Communication Quarterly 6 (2) 1999: 10-15. doi: 10.1080/15551399909363404

Manceaux, Michèle, and Jean Genet. “Jean Genet chez les 'Panthères noires.”. L'Obs. May 251970. https://www.nouvelobs.com/opinions/00004724.EDI0001/jean-genet-chez-les-pantheresnoires.html 
Margolick, David. Elizabeth and Hazel: Two Women of Little Rock. New Haven, Conn.: Yale UP, 2012.

Martindale, Carolyn. The White Press and Black America. New York: Greenwood Press, 1986.

Mary Phillips, and Angela Leblanc-Ernest. "The Hidden Narratives: Recovering and (Re)Visioning the Community Activism of Men in the Black Panther Party." Spectrum: A Journal on Black Men 5 (1) 2016: 63-89. Doi: 10.2979/spectrum.5.1.04

McDuffie, Erik S. "Black and Red: Black Liberation, the Cold War, and the Horne Thesis." Journal of African American History 96 (2) 2011: 236-47. doi: 10.5323/jafriamerhist.96.2.0236

McQuail, Denis. Mass Communication Theory: An Introduction. London: Sage, 1983

Meyer, Michaël. "De l'objet à l'outil: la photographie au service de l'observation en sciences sociales." RECHERCHES QUALITATIVES, Hors-Série 22 (2017): 8-23. http://www.recherchequalitative.qc.ca/documents/files/revue/hors_serie/HS-22/rq-hs22-meyer.pdf

Morley, Dave, and Stuart Hall. Family Television: Cultural Power and Domestic Leisure. Hoboken, NJ: Taylor \& Francis Ltd, 1986.

Nora, Pierre. Les Lieux de Mémoire, Tome 1 : La République. Paris: Gallimard, 1984.

Nunnelley, William A. Bull Connor. Tuscaloosa, Al.: U. of Alabama P., 1991

O'Hara, Mackie. Beyond Central, toward Acceptance: A Collection of Oral Histories from Students of Little Rock Central High. Little Rock, Ark.: Butler Center Books, 2010.

Ohrn, Karin Becker. How Photographs Become News: Photojournalists at Work. Corvallis, Or.: Association for Education in Journalism and Mass Communication Convention, 1983.

Patton, Stacey. Spare the Kids: Why Whupping Children Won't Save Black America. Boston, Ma.: Beacon press, 2017.

Payne, Charles M. “'Sexism Is a Helluva Thing': Rethinking Our Questions and Assumptions.” In Emilye Crosby (ed.). Civil Rights History from the Ground Up: Local Struggles, a National Movement. Athens, Ga.: U. of Georgia P., 2011: 319-29

Phu, T. N. "Shooting the Movement: Black Panther Party Photography and African American Protest Traditions." Canadian Review of American Studies 38 (1) 2008: 165-89. doi: 10.1353/crv. 0.0008

Raiford, Leigh. Imprisoned in a Luminous Glare: Photography and the African American Freedom Struggle. Chapel Hil, NC: U. of North Carolina P., 2011.

Rhodes, Jane. Framing the Black Panthers: The Spectacular Rise of a Black Power Icon. New York: New Press, 2007. http://www.jstor.org/stable/10.5406/j.ctt1m3216t .

Richardson, Riché. Black Masculinity and the U.S. South: From Uncle Tom to Gangsta. Athens, Ga.: U. of Georgia P., 2007.

Rustin, Bayard. "From Protest to Politics: The Future of the Civil Rights Movement |

Commentary." Commentary Magazine, February 1, 1965. https://www.commentarymagazine.com/ articles/from-protest-to-politics-the-future-of-the-civil-rights-movement/

Scannell, Paddy. Culture and Power: A Media, Culture \& Society Reader. London: SAGE, 1994.

Shames, Stephen. The Black Panthers. New York; London: Thames \& Hudson, 2006.

Shapiro, Herbert. White Violence and Black Response from Reconstruction to Montgomery. Amherst: U. of Massachusetts P., 1988. 
Shoemaker, Pamela J, and Stephen D Reese. Mediating the Message in the 21st Century: A Media Sociology Perspective. Hoboken, NJ: Taylor \& Francis, 2013.

Smaele, Hedwig de, Eline Geenen, and Rozane De Cock. "Visual Gatekeeping - Selection of News Photographs at a Flemish Newspaper.” Nordicom Review 38 (s2) 2017: 57-70. Doi : 10.1515/ nor-2017-0414

Snégaroff, Thomas. Little Rock, 1957: l'histoire des neuf lycéens noirs qui ont bouleversé l'Amérique. Paris: Taillandier, 2018.

Speltz, Mark. North of Dixie: Civil Rights Photography Beyond the South. Los Angeles: The J. Paul Getty Museum, 2016

Spencer, Robyn C. The Revolution Has Come: Black Power, Gender, and the Black Panther Party in Oakland. Durham / London: Duke UP, 2016.

Spratt, Margaret, Cathy Ferrand Bullock, Gerald Baldasty, Fiona Clark, Alex Halavais, Michael McCluskey, and Susan Schrenk. "News, Race, and the Status Quo: The Case of Emmett Louis Till." Howard Journal of Communications 18 (2) 2007: 169-92. doi: 10.1080/10646170701309924

Strain, Christopher B. Pure Fire: Self-Defense As Activism In The Civil Rights Era. Athens, Ga.: U. of Georgia P., 2005.

Strand, Paul. "Photography.” Alfred Stieglitz (ed.). Camera Works 49-50 (1917): 3-4.

Taft, Robert. Photography and the American Scene : A Social History, 1839-1889. New York, Macmillan, 1938.

Theoharis, Jeanne. "Black Freedom Studies: Re-Imagining and Redefining the Fundamentals." History Compass 4 (2) 2006: 348-67. Doi: 10.1111/j.1478-0542.2006.00318.x

Tisdale, John R. "Different Assignments, Different Perspectives: How Reporters Reconstruct the Emmett Till Civil Rights Murder Trial." The Oral History Review 29 (1) 2002: 39-58. https:// www.jstor.org/stable/3675800

Van Deburg, William L. "Black Villains and Social. Bandits in American Life; White Fear of the Black Cultural Revolution." In Brian Ward (ed.). Media, Culture, and the Modern African American Freedom Struggle. Gainesville: UP of Florida, 2001: 197-210.

Van Deburg, William L. Hoodlums: Black Villains and Social Bandits in American Life. Chicago, Ill.: U. of Chicago P., 2004.

Van Peebles, Melvin, and Kanopy (Firm). Sweet Sweetback's Baadasssss Song. Xenon Pictures, 1971. https://torontopl.kanopy.com/node/2411231

Walker, Jenny. “A Media-Made Movement." In Brian Ward (ed.). Media, Culture, and the Modern African American Freedom Struggle. Gainesville: UP of Florida, 2001: 41-66.

Ward, Brian (ed.). Media, Culture, and the Modern African American Freedom Struggle. Gainesville: UP of Florida, 2001.

Weill, Susan. In a Madhouse's Din: Civil Rights Coverage by Mississippi's Daily Press, 1948-1968. Westport, Conn.: Praeger, 2002

Williams, Jakobi. “'Don't No Woman Have to Do Nothing She Don't Want to Do': Gender, Activism, and the Illinois Black Panther Party." Black Women, Gender + Families 6 (2) 2012: 29-54. doi: 10.5406/blacwomegendfami.6.2.0029

Willis, Deborah. "Visualizing Political Struggle: Civil Rights-era Photography." In John Beck and David Holloway (ed.). American Visual Cultures. London: Continuum, 2005: 166-73 


\section{NOTES}

1. In 1936 Henry Luce relaunched Life as a major weekly news magazine with a strong emphasis on photojournalism. In the 1950s Life sold more than 13.5 million copies a week. After World War II new photographic magazines appeared: Ebony became a great money maker for its creator, John Johnson. But he also understood the impact of the positive image the black press put in circulation, even though the culture of a positive black imagery was not enough to resolve the problem of racism.

2. Sexism in the BPP was denounced by Elaine Brown who lead the party from 1974 to 1977: "A woman in the Black Power movement was considered, at best, irrelevant. A woman asserting herself was a pariah" (Brown 1992: 357). A gendered history of the BPP has been the object of various studies: LeBlanc-Ernest et Jones (1998); Mary Phillips \& Angela Leblanc-Ernest (2016); Huggins \& LeBlanc-Ernest (2009); Gore et al. (2009); Spencer (2016); Williams (2012); Payne (2011). For a recent bibliography see Antwanisha Alameen-Shavers's article and the intersectional Black Panther Party History project: https://iphpcom.wordpress.com/

3. "The term 'classical' appears especially apt for this phase of the civil rights movement" (Rustin 1965).

4. African Americans were among the pioneers in this medium which allowed them personal achievements but also collective advancement. Art historian Deborah Willis writes that: "African Americans have been part of photographic history for over 160 years, since its inception" (Willis 2002: XVII).

5. We borrow this concept from the French historian Pierre Nora (1984).

6. He was killed outside his home on June 12 by Byron de la Beckwith, who was imprisoned 31 years later thanks to Myrlie's obstinacy. Source: https://www.gettyimages.fr/detail/photod'actualit\%C3\%A9/tear-drops-down-the-face-of-myrlie-evers-at-her-photo-

dactualit\%C3\%A9/541222516\#/tear-drops-down-the-face-of-myrlie-evers-at-her-husband-

medgar-evers-picture-id541222516

7. The way Life has pictured the movement has been recently analyzed (Dibari 2017).

8. The children's crusade began on May 2 in Birmingham when the leaders of the Southern Christian Leadership Conference (SCLC), following James Bevel's strategy, asked the children to participate in the demonstrations.

9. Stanley Levison was one of the few people with Bayard Rustin who was not a Baptist pastor. Both had a political background within the Old Left, with which Levinson maintained ties. He had raised funds for the Communist Party and maintained informal links with that party.

10. Jane Rhodes provides an extensive analysis of their communication strategy by examining the keys to the success of this visual discourse and its impregnation in collective memory. Emory Douglas, the illustrator and draftsman who produced most of the BPP's drawings, is also the subject of several studies.

11. At the time the California gun laws were not as restrictive as they would later become, starting in 1967 with the Mulford Act, precisely designed against the Panthers.

12. That is, how Black Baptist women followed the normative dress code and moral norms in order to impose respect and attempt to claim a dignified place and status. Such respectability was also encouraged in demonstrators during the Civil Rights Movement, in order to show that African Americans had a place as equals in Southern society and also to counter the prevailing stereotypes on Blacks as crude and inferior beings.

13. COINTELPRO (1956-1971) is a term that covers various FBI projects against organizations and parties that were deemed as a threat to internal security. The Black Panther Party was their main target.

14. Ashley Farmer's recent book offers a study of black feminism since the 1930s and devotes several pages to Gayle Dickson (Farmer 2017). 
15. "Toute photographie est par nature d'histoire"

16. "La photographie emporte la conviction : comment la pellicule n'aurait-elle pas fixé la vérité ?"

\section{ABSTRACTS}

Photography has played an obvious role in black liberation movements. In the fight for civil rights, both the supporters of segregation and its opponents forged a stereotyped picture of their enemy. Our hypothesis is that the photographs from the mainstream media played an ambiguous role. They participated in the creation of two types of enemy shown as a threat to democracy: the hateful and violent white supporter of segregation, on the one hand, and the hateful and violent black nationalists, on the other. Their images testified against racism, but also circumscribed the movement to narrow legal objectives. The northern media created a two-sided picture of the black activists. First, to exonerate the northern liberals, they offered a reassuring view of racism in which the enemy was the violently racist white-trash barbarians from the Old South. In these pictures the southern activists are helpless victims, as was the case with Rosa Parks in the most widely distributed pictures of her. Second, the black nationalists were later portrayed as hateful and violent and disrespectful of American values. In doing so, the Northern media forged a dichotomy between a supposed peaceful and nonviolent movement before 1964, and a violent and useless black power era after 1965. But history is more complex than suggested by these well-known pictures.

La photographie a joué un rôle évident dans les mouvements de libération noirs. Dans la lutte pour les droits civiques, chaque camp, qu'il s'agisse des partisans de la ségrégation ou ses opposants, a forgé une image stéréotypée de l'ennemi. Nous faisons l'hypothèse que ces photographies, diffusée par les grands médias, ont joué un rôle ambigu. Elles ont participé à la création de deux types d'ennemis, deux menaces pour la démocratie : d'un côté le blanc haineux, violent partisan de la ségrégation, de l'autre le nationaliste noir, lui aussi haineux et violent. Avec ces photographies, les journaux cherchaient à témoigner contre le racisme mais ce faisant limitaient le mouvement à des objectifs juridiques étroits. Les médias du Nord ont ainsi créé une double image des militants noirs afin d'exonérer les libéraux du Nord : une vision " rassurante » du racisme, dans laquelle l'ennemi est représenté par les barbares blancs du Vieux Sud, violemment racistes. Dans ce discours visuel, les activistes du Sud sont des victimes impuissantes, telle Rosa Parks dans les photographies les plus connues. D'autre part, les nationalistes noirs sont dépeints comme haineux et racistes. Ce faisant, ces médias ont forgé une dichotomie entre un mouvement supposé pacifique avant 1964, et une ère du Black Power violente et inutile après 1964. Pourtant, l'histoire est plus complexe que ne le suggèrent ces images bien connues.

\section{INDEX}

Keywords: Civil Rights Movement, Black Power, photography, Black Panther Party, Little Rock, stereotypes, historiography, United States, enemy

Mots-clés: Mouvement des Droits Civiques, Black Power, photographie, Parti des Panthères Noires, Little Rock, stéréotypes, historiographie, États-Unis, ennemi 


\section{AUTHOR}

\section{OLIVIER MAHEO}

Post-doctoral assistant, Assistant Université de Poitiers, CRIHAM. Sorbonne Nouvelle, ED 625, CREW. Contact: olivier.maheo(at]univ-Poitiers.fr 